\title{
Article \\ Community Risk Factors in the COVID-19 Incidence and Mortality in Catalonia (Spain). A Population-Based Study
}

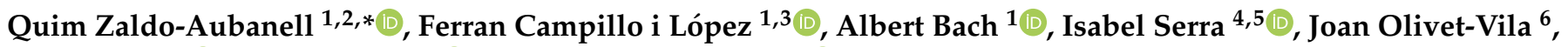 \\ Marc Saez ${ }^{7,8}$ (D) David Pino ${ }^{9,10}$ (D) and Roser Maneja 1,11,12
}

check for

updates

Citation: Zaldo-Aubanell, Q.; Campillo i López, F.; Bach, A.; Serra, I.; Olivet-Vila, J.; Saez, M.; Pino, D.; Maneja, R. Community Risk Factors in the COVID-19 Incidence and Mortality in Catalonia (Spain). A Population-Based Study. Int. J. Environ. Res. Public Health 2021, 18 3768. https://doi.org/10.3390/ ijerph18073768

Academic Editor: Paul Tchounwou

Received: 24 February 2021

Accepted: 2 April 2021

Published: 4 April 202

Publisher's Note: MDPI stays neutral with regard to jurisdictional claims in published maps and institutional affiliations.

Copyright: (c) 2021 by the authors. Licensee MDPI, Basel, Switzerland. This article is an open access article distributed under the terms and conditions of the Creative Commons Attribution (CC BY) license (https:// creativecommons.org/licenses/by/ $4.0 /)$
1 Environment and Human Health Laboratory (EH2 Lab), Forest Science and Technology Center of Catalonia, Ctra. de St. Llorenç de Morunys, km 2, 25280 Solsona, Spain; FCAMPILLO@hospiolot.cat (F.C.iL.); albert.bach@uab.cat (A.B.); roser.maneja@uab.cat (R.M.)

2 Institute of Environmental Science and Technology (ICTA), Autonomous University of Barcelona (UAB), Z Building, ICTA-ICP, Carrer de les Columnes, UAB Campus, 08193 Bellaterra, Spain

3 Pediatric Environmental Health Specialty Unit, Pediatric Team of Garrotxa and Ripollès Regions, Olot and Garrotxa Region Hospital Foundation, 17800 Olot, Spain

4 Centre de Recerca Matemàtica, Edifici C, 08193 Bellaterra, Spain; iserra@crm.cat

5 Barcelona Supercomputing Center, 08034 Barcelona, Spain

6 Health Promotion Service in Girona, Agency of Public Health of Catalonia, Generalitat of Catalonia, 17003 Girona, Spain; jolivetv@gencat.cat

7 Research Group on Statistics, Econometrics and Health (GRECS), University of Girona, 17003 Girona, Spain; marc.saez@udg.edu

8 CIBER of Epidemiology and Public Health (CIBERESP), 28029 Madrid, Spain

9 Departament of Physics, Universitat Politècnica de Catalunya BarcelonaTech, Esteve Terrades 5, 08034 Castelldefels, Spain; david.pino@upc.edu

10 Institut d'Estudis Espacials de Catalunya (IEEC-UPC), Gran Capità 2-4, 08034 Barcelona, Spain

11 Forest Science and Technology Center of Catalonia, Ctra. de St. Llorenç de Morunys, km 2, 25280 Solsona, Spain

12 Geography Department, Autonomous University of Barcelona (UAB), B Building, UAB Campus, 08193 Bellaterra, Spain

* Correspondence: quim.zaldo@uab.cat; Tel.: +34-620-030-215

Abstract: The heterogenous distribution of both COVID-19 incidence and mortality in Catalonia (Spain) during the firsts moths of the pandemic suggests that differences in baseline risk factors across regions might play a relevant role in modulating the outcome of the pandemic. This paper investigates the associations between both COVID-19 incidence and mortality and air pollutant concentration levels, and screens the potential effect of the type of agri-food industry and the overall land use and cover (LULC) at area level. We used a main model with demographic, socioeconomic and comorbidity covariates highlighted in previous research as important predictors. This allowed us to take a glimpse of the independent effect of the explanatory variables when controlled for the main model covariates. Our findings are aligned with previous research showing that the baseline features of the regions in terms of general health status, pollutant concentration levels (here $\mathrm{NO}_{2}$ and $\mathrm{PM}_{10}$ ), type of agri-food industry, and type of land use and land cover have modulated the impact of COVID-19 at a regional scale. This study is among the first to explore the associations between COVID-19 and the type of agri-food industry and LULC data using a population-based approach. The results of this paper might serve as the basis to develop new research hypotheses using a more comprehensive approach, highlighting the inequalities of regions in terms of risk factors and their response to COVID-19, as well as fostering public policies towards more resilient and safer environments.

Keywords: COVID-19; air pollutants; cardiovascular diseases; psychological disorders; cancer; agri-food industry; land use and land cover data 


\section{Introduction}

The COVID-19 pandemic, caused by the Severe Acute Respiratory Syndrome Coronavirus 2 (SARS-CoV-2), has become a leading health concern worldwide. As of 31 May 2020 , there were $5,939,234$ confirmed cases and 367,255 deaths globally [1]. The severity and mortality have been related to aging and pre-existent health conditions, including respiratory and cardiovascular diseases, as well as psychological disorders and cancer $[2,3]$. Nevertheless, the geographic COVID-19 distribution within countries or regions has been uneven [4]. Socioeconomic status has also been pointed out as a community determining factor, but inconsistently for both richer and poorer populations $[5,6]$. In the same direction, inconclusive results have been found regarding population density [6-8]. Previous studies have reported the association between population physical distancing and COVID-19 spreading dynamics [9-11], as well as other weather conditions such as humidity and temperature [12]. These links might lie behind the local outbreaks of the pandemic in certain agri-food sectors such as meat and leather and fur industries [13,14]. However, other studies have recently pointed out that COVID-19 incidence correlates to ultraviolet radiation, rather than temperature-humidity $[15,16]$.

Air pollution remains one of the main threats for human health worldwide and can also play a relevant role in the COVID-19 crisis mainly in two ways: increasing the severity of the virus' clinical effects in chronically exposed populations and, probably to a lesser extent, promoting the virus' airborne dispersion [17-19]. On one hand, according to the World Health Organization (WHO), there are 4.2 million deaths every year mostly due to cardiorespiratory diseases as a result of exposure to outdoor air pollution [20]. Recent studies have shown that ambient air pollution may be linked to the lethality of COVID-19 in Asia, Europe and America [21-26]. Thus, regions chronically exposed to nitrogen dioxide $\left(\mathrm{NO}_{2}\right)$ and particulate matter $\left(\mathrm{PM}_{2.5}\right.$ and $\left.\mathrm{PM}_{10}\right)$ seem to be more susceptible to the virus. Still, many of those studies do not include well identified health covariates [27-29] and are focused only on mortality. On the other hand, some authors have studied the role of particulate matter in the spreading of SARS-CoV-2 [12,30-32], principally in industrialised areas [33].

Air pollution and aerosol formation and distribution have been widely linked to Land Use and Land Cover (LULC) [34-36], with an especial concern regarding particulate matter $\left(\mathrm{PM}_{2.5}\right.$ and $\left.\mathrm{PM}_{10}\right)$ [37-39]. In this sense, urbanised and industrial areas are associated with worse air quality than other LULC categories such as agricultural or forested areas [39]. LULC information is useful open source data which is associated with other factors like population density, biodiversity and economic activities [40], and has been identified as a suitable describer of the environment in studies relating the environment to human health [41]. For the aforementioned, research encompassing the associations between COVID-19 and LULC data appears to be relevant, since this spatial data (LULC) leverage socioeconomic and biophysical information of the environment.

In Catalonia (Spain), there was a heterogenous distribution of both COVID-19 incidence and mortality in the early stages of the pandemic. This suggests that differences in baseline risk factors across regions might have modulated the outcome of the pandemic. The purposes of this study are to:

1. Analyse the associations between both COVID-19 incidence and mortality and longterm exposure to pollutant concentration $\left(\mathrm{NO}_{2}\right.$ and $\left.\mathrm{PM}_{10}\right)$, while adjusting for demographic information, socioeconomic status and general health status (cardiovascular diseases, psychological disorders and all-cause cancer);

2. Explore the potential links between agri-food industry and COVID-19 incidence and mortality as observed from the outbreaks in these particular industries;

3. Screen, for the very first time, the potential use of the overall Land Use and Cover data on describing the geographical COVID-19 incidence and mortality. 


\section{Materials and Methods}

\subsection{COVID-19 Cases and Deaths}

The number of patients infected with SARS-CoV-2 (cases) and deaths attributed to COVID-19 in Catalonia were gathered until 18 May 2020, after the first peak decreased and the incidence of new cases started to stabilise.

The number of cases was obtained from the RSAcovid19 records from the Catalan Health Department. We collected both the positive cases (patients positively diagnosed by a PCR-Polymerase Chain Reaction-or rapid diagnostic test) and suspicions cases (patients who presented symptoms compatible with COVID-19 and were classified as a possible case, even though they were diagnosed neither by a PCR nor by a rapid diagnostic test). All of them were active cases under the control of Epidemiologic Surveillance Service in Catalonia and were attributed to their residential Basic Health Area (BHA), the fundamental territorial unit through which Catalan Healthcare System is articulated and the unit of analysis of this paper. In total, 372 BHA compose the Catalan territory.

The number of registered deaths due to COVID-19 was obtained from the Catalan Agency for Health Quality and Evaluation (AQuAS) and the Central Register of Insured Persons of the Catalan Health Department. These data included not only people who were positively diagnosed by a laboratory test but also people who presented symptoms compatible with the illness. These open data are updated several times per day, so analyses and figures might change depending on the date. Furthermore, death observations might be modified by the Mortality Register of Catalonia once all death certificates have been collected [42].

Both data sets were provided already segmented by sex (male and female). Incidence and mortality rates were calculated using the number of cases and the number of deaths divided by the total amount of population within each BHA. Figures S1 and S2 show the COVID-19 incidence and mortality rates, respectively (see Supplementary Information Section).

\subsection{Comorbidities}

During the first wave of the pandemic in Catalonia, COVID-19 tests were not conducted on every person showing symptoms. Rather, people with more severe symptoms or having pre-existent health conditions were more likely to be tested and thus, finally diagnosed. To control for the general health status of each BHA, we created three groups of principal health conditions explored by previous literature: cardiovascular diseases; psychological disorders and all-cause cancer. Pre-existent respiratory conditions could not be considered as the health dataset was incomplete.

The percentages of people presenting cardiovascular diseases (congestive heart failure, hypertension, ischemic cardiomyopathy and patients who suffered cerebrovascular accident), psychological disorders (depression, schizophrenia, intellectual disability, conduct disorder, attention deficit disorder and psychosis), and all-cause cancer were obtained from historical observational data from 2014 provided by the Catalan Health Department and the Catalan Agency for Health Quality and Evaluation (AQuAS). We lacked more recent data to control for the general health status of BHAs. However, the health outcomes assessed were prevalent illnesses with generally slight changes from one year to another. The data was aggregated by BHA and sex (male and female).

\subsection{Demographic and Socioeconomic Data}

Some authors have highlighted the prominent impacts of COVID-19 on elderly people, especially in nursing homes [43]. Others have also focused their studies in the importance of sex [44]. We controlled for sex and elderly people by calculating the percentage of people over the age of sixty-five in each BHA and distinguishing the COVID-19 cases and deaths between males and females. In addition, socioeconomic data were extracted from the Catalan Health Observatory. We used the Composed Socioeconomic Index (CSI) [45], that is calculated for each BHA. This index is used in the assessment of resources 
for Primary Health, which includes a set of socioeconomic variables: economic income, education, professional occupation, life expectancy, premature death rate and preventable hospitalizations rate. This is a continuous variable measured from 0 to 100 ( 0 being the poorest and 100 the richest). Previous works have suggested dividing such data into septiles [3]. However, after testing the model, we opted for using quintiles from a very low $(\mathrm{E} ; \mathrm{CSI} \geq 0$ and $<20)$ to a very high $(\mathrm{A} ; \mathrm{CSI} \geq 80$ ) socioeconomic status (SES).

\subsection{Air Pollution}

Long-term exposure to air pollutants was assessed using the modelling of the $\mathrm{NO}_{2}$ and $\mathrm{PM}_{10}$ annual average $\left(\mu \mathrm{g} / \mathrm{m}^{3}\right)$ in Catalonia, corresponding to the 2016 assessment from the General Direction of Environmental Quality and Climate Change of the Catalan Government.

We calculated the annual weighted average for each BHA through GRASS GIS (GRASS Development Team, 2017. Geographic Resources Analysis Support System (GRASS) Software, Version 7.2. Open Source Geospatial Foundation. Electronic document: http: / /grass.osgeo.org (accessed on 23 May 2020)) (see Figures S3 and S4 of Supplementary Information Section showing the annual weighed average of $\mathrm{NO}_{2}$ and $\mathrm{PM}_{10}\left(\mu \mathrm{g} / \mathrm{m}^{3}\right)$ for each BHA (2016)).

Besides air pollution data from 2016, we created a dataset for the period 2018-2019 (the most up-to-date period with data available). We combined three data sources (pollution data from the Catalan Government; Smart Citizen, a citizen science project from the European Community's H2020; and pollution data from the European Environment Agency). Then, we calculated the annual average for each pollutant in each BHA containing sensors, which yielded $63 \mathrm{BHAs}$ with values for $\mathrm{NO}_{2}$ and 91 with values for $\mathrm{PM}_{10}$. After controlling for possible differences between both periods (2016 and 2018/2019) and finding no significant differences, we chose the modelling of the $\mathrm{NO}_{2}$ and $\mathrm{PM}_{10}$ annual average for 2016 because it provided information for all Catalonia. Results of the two independent t-tests assessing significant differences between pollutant concentration levels $\left(\mathrm{NO}_{2}\right.$ and $\mathrm{PM}_{10}$ ) in 2016 and in 2018/2019 are provided in the Results section.

Other air pollutants have been widely used to assess pollution levels. Previous research hypothesised that long-term exposure to $\mathrm{O}_{3}$ and $\mathrm{PM}_{2.5}$ adversely affects the respiratory and cardiovascular systems, increasing mortality risk and also exacerbating the severity of COVID-19, worsening the prognosis of the disease $[46,47]$. In this sense, $\mathrm{O}_{3}$ levels has been found to be associated with COVID-19 confirmed cases [48] and $\mathrm{PM}_{2.5}$ to be a highly significant predictor of the number of confirmed COVID-19 cases, deaths and hospital admissions [48,49]. Although assessment of the independent effect of the abovementioned pollutants would have been of interest, we only used $\mathrm{NO}_{2}$ and $\mathrm{PM}_{10}$ data, as they were provided for all Catalan territory.

\subsection{Agri-Food Industry}

Agri-food industry geographic information was extracted from Catalan Agri-food industry Records (http:/ /agricultura.gencat.cat/ca/serveis/registres-oficials/agroaliment acio/registre-industries-agraries-alimentaries-catalunya/ (accessed on 1 June 2020)). The industries are classified depending on their industrial sector: slaughter of livestock, conservation and elaboration of meat products; preparation and conservation of fish, crustaceans and molluscs; preparation and preservation of fruits and vegetables; manufacturing of vegetables and animal oils and fats; manufacturing of milk products; manufacturing of grain mill products, starches and starch products; manufacturing of bakery and pasta products; manufacturing of other food products; manufacturing of products for animal feeding; manufacturing of beverages; forest industries; and other agricultural industries.

We split the category "other agricultural industries" into two main subtypes: "Leather and fur industry" (industries based on preparation, tanning and dyeing animal skins) and "Garden industry" (industries based on seed conditioning and handling, substrate production and ornamental plant conservation), as we considered that these two sectors 
were poorly represented in the above classification. The total number of industries of each type was collected within each BHA.

\subsection{Land Use and Land Cover Data}

To describe the environment of each BHA we used the most updated and detailed Land Use and Land Cover data of Catalonia, the Land Use and Cover map for 2017. This is a tool generated with automated image classification of a 30-m resolution. The images are obtained thought Landsat satellite (Landsat-5, Landsat-7, Landsat-8 and Sentinel-2) using both their sensors Thematic Mapper (TM), Enhanced Thematic Mapper Plus (ETM+), Operational Land Imager (OLI) and Multispectral Imager (MSI), and complementary information such as the Urban Map of Catalonia and the graph of the Catalonia infrastructures network. It also incorporates the cartographic database of forest fires from the Ministry of Agriculture, Livestock, Fisheries and Food of Catalonia, and the LIDAR database from the Institut Cartogràfic i Geològic de Catalunya (ICGC) (http://territori.gencat.cat/ca/01_departament/1 2_cartografia_i_toponimia/bases_cartografiques/medi_ambient_i_sostenibilitat/bases_mi ramon/territori/mapa-dusos-i-cobertes-del-sol/index.html (accessed on 30 May 2020))

As Table 1 shows, we reclassified the 25 Land Use and Land Cover (LULC) categories into four broader categories: urban areas; industrial, commercial and transport units; agricultural areas; and forest and semi-natural areas. In this classification, categories referring to water bodies (inland and marine waters) and bare land were not considered due to their low significance.

Table 1. Reclassification of the 25 LULC categories of the Land Use and Cover Map of Catalonia (2017) into four broader categories.

\begin{tabular}{|c|c|c|c|}
\hline Urban Areas & $\begin{array}{c}\text { Industrial, Commercial and } \\
\text { Transport Units }\end{array}$ & Agricultural Areas & $\begin{array}{c}\text { Forest and Semi-NATURAL } \\
\text { Areas }\end{array}$ \\
\hline Discontinuous urban fabric & Industrial or commercial units & Permanently irrigated land & Lowland natural grasslands \\
\hline \multirow[t]{7}{*}{ Continuous urban fabric } & $\begin{array}{l}\text { Road and rail networks and } \\
\text { associated land }\end{array}$ & Non-irrigated arable land & Montane natural grasslands \\
\hline & & Unirrigated Fruit tress & Alpine natural grasslands \\
\hline & & Irrigated Fruit trees & Transitional woodland/shrub \\
\hline & & Vineyards & Wetland vegetation \\
\hline & & Rice fields & Coniferous forest \\
\hline & & Citrus trees & Broad-leaved forest \\
\hline & & & Sclerophyll forest \\
\hline
\end{tabular}

When proportions of land use and cover composing geographical regions are analysed, each observation is a vector of proportions of specific LULC categories [50]. This characteristic raises the problem of singularity (a constant sum constraint) as the vectors (also called compositions) describe the relative contribution of each part (the components) on the whole. So the information is present in the ratios of the components rather than in each component [51-53]. Following Müller et al. (2018) [54], we avoided the singularity constraint by applying an isometric logratio (ilr) transformation to the four LULC variables. This transformation moves the compositions isometrically from the simplex with the Aitchison geometry to the standard real space with the Euclidean one [53]. As recommended [54], we used a $\log 2$ transformation, as it facilitated the understanding of the estimates. With this transformation, a unit additive increment in the ilr-transformed variable is equal to a two-fold multiplicative increase in the relative dominance of the original composition variable $\mathrm{x}$, as a base-2 logarithm is used. In other words, this means that the relative dominance of a specific LULC category is doubled in comparison to the geometric mean of all the rest LULC variables [54]. 


\subsection{Statistical Analysis}

To assess the associations between COVID-19 incidence and mortality and the explanatory variables, we fitted a generalised linear model, in the binomial family, with a logit link. This model fit was selected as the dependent variable followed a Binomial distribution.

$$
\begin{gathered}
Y_{i} \sim \operatorname{Bernoulli}\left(p_{i}\right) \text { for } i=1, \ldots, n . \\
\operatorname{Logit}\left(\mu_{i}\right)=\log \left(\frac{p_{i}}{1-p_{i}}\right)=\beta_{0}+\sum_{i=1}^{n} \beta_{i} \times X_{i},
\end{gathered}
$$

where $Y_{i}$ was the binary (Bernoulli) response variable; $p_{i}$ was the probability of successes $P\left(Y_{i}=1\right)$, in this case, 1 stands for a confirmed COVID-19 case or death; $\mu_{i}$ is the expected value of each $Y_{i}$ which is equal to the probability of successes $p_{i} ; \beta_{0}$ is the intercept, and $\beta_{i}$ denotes the logistic regression coefficients for the design matrix $X$ of covariables $i$.

Logistic regression analyses with 95\% Wald confidence intervals (95\% CI) were performed to assess the association between both incidence and mortality rate of COVID-19 (number of confirmed COVID-19 cases or deaths within a given BHA/total number of people living within such BHA) and the rest of covariates, while adjusting for demographics, socioeconomic and comorbidity covariates. The model was fitted using population size of each BHA as weights. We built a main model using the demographics, socioeconomic and comorbidity covariates and then, human activity covariates, as well as land use and cover covariates, were included in the model separately (see Table 2).

\begin{tabular}{|c|c|}
\hline Covariate (Units) & Description \\
\hline \multicolumn{2}{|r|}{ Demographics, socioeconomic status, and comorbidity (Main model) } \\
\hline Sex: Females & Categorical variable comparing females to males, used as a reference level. \\
\hline Percent $>65(\%)$ & Percentage of people aged above 65 years. \\
\hline $\begin{array}{l}\text { SES A } \\
\text { SES B } \\
\text { SES D } \\
\text { SES E }\end{array}$ & $\begin{array}{l}\text { Socioeconomic status categorised with } 5 \text { levels, comparing very high, high, low and very low (A, } \\
\text { B, D, E) socioeconomic status to normal (C), used as the reference level. Data from } 2014 \text {. }\end{array}$ \\
\hline Cardiovascular diseases $(\%)$ & $\begin{array}{l}\text { Group variable. Percentage of people with congestive heart failure, hypertension, ischemic } \\
\text { cardiomyopathy or who suffered cerebrovascular accident in } 2014 \text {. }\end{array}$ \\
\hline Psychological disorders (\%) & $\begin{array}{l}\text { Group variable. Percentage of people with depression, schizophrenia, intellectual disability, } \\
\text { conduct disorder, attention deficit disorder or psychosis in } 2014 .\end{array}$ \\
\hline All-cause cancer $(\%)$ & Group variable. Percentage of people with any type of cancer in 2014. \\
\hline \multicolumn{2}{|r|}{ Human activity } \\
\hline $\mathrm{NO}_{2}\left(\mu \mathrm{g} / \mathrm{m}^{3}\right)^{*}$ & Nitrogen dioxide annual weighed average in 2016. \\
\hline $\mathrm{PM}_{10}\left(\mu \mathrm{g} / \mathrm{m}^{3}\right) *$ & Particulate matter with diameter of $10 \mu \mathrm{m}$ annual weighed average in 2016. \\
\hline Meat industry* & $\begin{array}{l}\text { Number of industries based on slaughtering of livestock, conservation and elaboration of meat } \\
\text { products in } 2020 .\end{array}$ \\
\hline Fish industry * & $\begin{array}{l}\text { Number of industries based on preparation and conservation of fish, crustaceans and molluscs } \\
\text { in } 2020 .\end{array}$ \\
\hline Vegetable industry * & Number of industries based on preparation and preservation of fruits and vegetables in 2020 . \\
\hline Animal oils and fats * & Number of industries based on manufacturing of vegetable and animal oils and fats in 2020. \\
\hline Milk products * & Number of industries based on manufacturing of milk products in 2020 . \\
\hline Grain mill industry * & $\begin{array}{c}\text { Number of industries based on manufacturing of grain mill products, starches and starch } \\
\text { products in } 2020 .\end{array}$ \\
\hline
\end{tabular}

Table 2. Covariates tested in the model. All the variables were calculated within each BHA, the unit of analysis. 
Table 2. Cont.

\begin{tabular}{|c|c|}
\hline Covariate (Units) & Description \\
\hline Bakery industry* & Number of industries based on manufacturing of bakery and pasta products in 2020 . \\
\hline Other food products * & Number of industries based on manufacturing of other food products in 2020 . \\
\hline Animal feeding * & Number of industries based on manufacturing of products for animal feeding in 2020. \\
\hline Beverage industry* & Number of industries based on manufacturing of beverages in 2020 . \\
\hline Forest industry * & Number of forest industries in 2020. \\
\hline Leather and fur industry * & Number of industries based on preparation, tanning and dyeing animal skins in 2020. \\
\hline Garden industry* & $\begin{array}{l}\text { Number of industries based on seed conditioning and handling, substrate production and } \\
\text { ornamental plant conservation in } 2020 .\end{array}$ \\
\hline \multicolumn{2}{|r|}{ Land use and Land cover } \\
\hline ilr-Urban areas * & $\begin{array}{l}\text { Isometric logratio (ilr) transformation of the percentage of urban areas in a given BHA. } \\
\text { Numerical variable. }\end{array}$ \\
\hline ilr-Industrial areas * & $\begin{array}{l}\text { Isometric logratio (ilr) transformation of the percentage of industrial, commercial and transport } \\
\text { unit areas in a given BHA. Numerical variable. }\end{array}$ \\
\hline ilr-Agricultural areas * & $\begin{array}{l}\text { Isometric logratio (ilr) transformation of the percentage of agricultural areas in a given BHA. } \\
\text { Numerical variable. }\end{array}$ \\
\hline ilr-Forested areas * & $\begin{array}{c}\text { Isometric logratio (ilr) transformation of the percentage of forested and semi-natural areas in a } \\
\text { given BHA. Numerical variable. }\end{array}$ \\
\hline
\end{tabular}

* Variables were included in the model separately.

Statistical analysis were conducted using the $\mathrm{R}$ language environment for statistical computing, R version 3.6.2 (12 December 2019) [55].

\section{Results}

Homogeneity of groups in terms of pollutant concentration levels was assessed using two independent t-tests (Table 3 ) for the specific BHA which we had available information (63 BHA, for $\mathrm{NO}_{2}$; and $91 \mathrm{BHA}$, for $\mathrm{PM}_{10}$ ). Based on the t-tests outcomes, no significant differences were noted between the annual average of pollutants in 2016 and in 2018/2019 for neither pollutant $\left(\mathrm{NO}_{2} ; t=0.792, p=0.428\right.$, and $\left.\mathrm{PM}_{10} ; t=-1.559, p=0.119\right)$.

Table 3. Independent t-tests between mean pollutant concentration levels in 2016 and in 2018/2019.

\begin{tabular}{|c|c|c|c|c|c|}
\hline \multirow[b]{2}{*}{ Variables } & \multicolumn{2}{|c|}{ Mean \pm SD } & \multicolumn{3}{|c|}{ Statistical Results } \\
\hline & $\begin{array}{c}2016 \\
\text { Concentration Levels }\end{array}$ & $\begin{array}{c}\text { 2018/2019 } \\
\text { Concentration Levels }\end{array}$ & df & $t$ & $p$-Value \\
\hline $\mathrm{NO}_{2}$ & $20.23 \pm 12.163$ & $21.37 \pm 10.700$ & 246 & 0.792 & 0.428 \\
\hline $\mathrm{PM}_{10}^{2}$ & $21.52 \pm 4.397$ & $20.72 \pm 5.241$ & 351.37 & -1.559 & 0.119 \\
\hline
\end{tabular}

The adjusted odds ratio (OR) with $95 \%$ confidence intervals for the association between COVID-19 incidence and mortality and the explored covariates are shown in Table 4 and also represented in Figure S6 (see Supplementary Information section). 


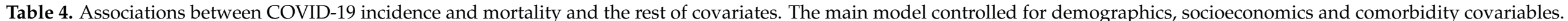

Human activity covariates as well as land use and cover covariates were included in the model separately.

\begin{tabular}{|c|c|c|c|c|c|c|c|c|}
\hline \multirow[b]{3}{*}{ Covariates } & \multicolumn{4}{|c|}{ Incidence of COVID-19 } & \multicolumn{4}{|c|}{ Mortality of COVID-19 } \\
\hline & \multicolumn{2}{|c|}{ Adjusted Main Model } & \multicolumn{2}{|c|}{ Unadjusted } & \multicolumn{2}{|c|}{ Adjusted Main Model } & \multicolumn{2}{|c|}{ Unadjusted } \\
\hline & Odds Ratio (95\% CI) & $p$-Value & Odds Ratio (95\% CI) & $p$-Value & Odds Ratio (95\% CI) & $p$-Value & Odds Ratio (95\% CI) & $p$-Value \\
\hline \multicolumn{9}{|l|}{ Main Model } \\
\hline Percent $>65$ & $1.006(1.0047-1.0072)$ & $* * *$ & 1.018 (1.0171-1.0189) & $* * *$ & $1.023(1.0171-1.0281)$ & $* * *$ & $1.052(1.0481-1.0562)$ & $* * *$ \\
\hline SES A (very high) & 1.199 (1.1832-1.2150) & $* * *$ & 1.171 (1.1568-1.1848) & $* * *$ & 1.547 (1.4556-1.6434) & $* * *$ & $1.523(1.4414-1.6093)$ & $* * *$ \\
\hline SES B (high) & 1.126 (1.1116-1.1402) & $* * *$ & $1.153(1.1387-1.1674)$ & $* * *$ & $1.241(1.1696-1.3166)$ & $* * *$ & $1.346(1.2702-1.4271)$ & $* * *$ \\
\hline SES D (low) & $0.967(0.9542-0.9800)$ & $* * *$ & $0.998(0.9849-1.0114)$ & - & $0.914(0.8573-0.9754)$ & * & $1.015(0.9517-1.0815)$ & - \\
\hline SES E (very low) & $0.956(0.9432-0.9688)$ & $* * *$ & $0.994(0.9806-1.0067)$ & - & $0.908(0.8511-0.9677)$ & ** & $1.011(0.9493-1.0778)$ & - \\
\hline Psychological disorders & 1.148 (1.1418-1.1545) & $* * *$ & 1.057 (1.0517-1.0627) & $* * *$ & $1.312(1.2809-1.3435)$ & $* * *$ & $1.255(1.2282-1.2827)$ & $* * *$ \\
\hline All-cause cancer & $1.021(1.0153-1.0258)$ & $* * *$ & $1.084(1.0805-1.0883)$ & $* * *$ & $1.102(1.0774-1.1272)$ & $* * *$ & $1.239(1.2205-1.2584)$ & $* * *$ \\
\hline \multicolumn{9}{|l|}{ Human activity } \\
\hline $\mathrm{NO}_{2}$ & $0.999(0.9989-0.9996)$ & $* * *$ & 1.002 (1.0014-1.0020) & $* * *$ & $1.013(1.0118-1.0151)$ & $* * *$ & $1.017(1.0154-1.0182)$ & $* * *$ \\
\hline $\mathrm{PM}_{10}$ & $1.003(1.0015-1.0038)$ & $* * *$ & $1.009(1.0077-1.0098)$ & $* * *$ & $1.048(1.0421-1.0541)$ & $* * *$ & $1.050(1.0451-1.0559)$ & $* * *$ \\
\hline Meat industry & $1.002(1.0012-1.0019)$ & $* * *$ & 1.001 (1.0006-1.0014) & $* * *$ & $0.995(0.9926-0.9965)$ & $* * *$ & $0.992(0.9900-0.9938)$ & $* * *$ \\
\hline Fish industry & $0.993(0.9911-0.9951)$ & $* * *$ & $0.982(0.9799-0.9840)$ & $* * *$ & $0.964(0.9536-0.9755)$ & $* * *$ & $0.929(0.9177-0.9412)$ & $* * *$ \\
\hline Vegetable industry & $0.988(0.9867-0.9885)$ & $* * *$ & $0.985(0.9839-0.9856)$ & $* * *$ & $0.941(0.9340-0.9478)$ & $* * *$ & $0.923(0.9154-0.9300)$ & $* * *$ \\
\hline Animal oils and fats & $0.982(0.9812-0.9836)$ & $* * *$ & $0.980(0.9789-0.9813)$ & $* * *$ & $0.909(0.8988-0.9189)$ & $* * *$ & $0.888(0.8781-0.8991)$ & $* * *$ \\
\hline Milk products & 1.000 (0.9982-1.0013) & - & $1.001(0.9995-1.0024)$ & - & $0.973(0.9650-0.9806)$ & $* * *$ & $0.975(0.9675-0.9822)$ & $* * *$ \\
\hline Other food products & $0.984(0.9829-0.9861)$ & $* * *$ & $0.977(0.9752-0.9783)$ & $* * *$ & $0.933(0.9244-0.9412)$ & $* * *$ & $0.910(0.9019-0.9178)$ & $* * *$ \\
\hline Animal feeding & 0.998 (0.9967-0.9994) & $* *$ & $0.999(0.9975-1.0001)$ & - & $0.970(0.9630-0.9768)$ & $* * *$ & $0.967(0.9605-0.9739)$ & $* * *$ \\
\hline Beverage industry & 0.999 (0.9994-0.9996) & $* * *$ & $0.999(0.9994-0.9996)$ & $* * *$ & $0.998(0.9970-0.9983)$ & $* * *$ & $0.997(0.9963-0.9978)$ & $* * *$ \\
\hline Forest industry & 1.004 (1.0011-1.0077) & * & $0.990(0.9869-0.9931)$ & $* * *$ & $0.945(0.9278-0.9632)$ & $* * *$ & $0.907(0.8911-0.9240)$ & $* * *$ \\
\hline Leather and fur industry & 1.070 (1.0624-1.0779) & $* * *$ & $1.078(1.0702-1.0856)$ & $* * *$ & 1.110 (1.0776-1.1441) & $* * *$ & $1.115(1.0823-1.1489)$ & $* * *$ \\
\hline Garden industry & $0.922(0.9122-0.9329)$ & $* * *$ & $0.922(0.9119-0.9321)$ & $* * *$ & $0.717(0.6715-0.7649)$ & $* * *$ & $0.709(0.6649-0.7560)$ & $* * *$ \\
\hline \multicolumn{9}{|l|}{ Land use and cover } \\
\hline ilr-Urban areas & $1.006(1.0048-1.0076)$ & $* * *$ & $1.013(1.0114-1.0136)$ & $* * *$ & $1.050(1.0440-1.0569)$ & $* * *$ & $1.062(1.0566-1.0669)$ & $* * *$ \\
\hline ilr-Industrial areas & $0.990(0.9884-0.9921)$ & $* * *$ & $0.991(0.9892-0.9926)$ & $* * *$ & 1.039 (1.0304-1.0477) & $* * *$ & $1.036(1.0281-1.0442)$ & $* * *$ \\
\hline ilr-Agricultural areas & $0.982(0.9806-0.9835)$ & $* * *$ & $0.977(0.9762-0.9786)$ & $* * *$ & $0.936(0.9303-0.9422)$ & $* * *$ & $0.925(0.9200-0.9300)$ & $* * *$ \\
\hline ilr-Forested areas & $1.014(1.0131-1.0158)$ & $* * *$ & $1.012(1.0111-1.0136)$ & $* * *$ & $0.991(0.9856-0.9971)$ & $* *$ & $0.987(0.9816-0.9925)$ & $* * *$ \\
\hline
\end{tabular}

- non-statistically significant; ${ }^{*} p$-value $<0.05 ;{ }^{* *} p$-value $<0.005 ;{ }^{* * *} p$-value $<0.0005$. 
In the main model using demographic, socioeconomic and comorbidity covariables, BHAs with more percentage of people aged above 65 years, of A (very high) and B (high) socioeconomic status (SES) showed a positive association with both COVID-19 incidence and mortality. In these cases, estimates for mortality were greater than for incidence. Contrarily, BHAs of D (low) and E (very low) SES were associated with decreased levels of COVID-19 incidence and mortality. However, when tested alone (without adjusting for the rest of covariates), they showed a non-significant effect.

All three comorbidity variables were positively associated with both COVID-19 incidence (OR 1.003 95\% 1.0020-1.0049 for cardiovascular diseases; OR 1.148 95\% 1.1418-1.1545 for psychological disorders; and OR 1.021 95\% 1.0153-1.0258 for all-cause cancer) and mortality (OR 1.007 95\% 1.0006-1.0136 for cardiovascular diseases; OR 1.312 95\% 1.2809-1.3435 for psychological disorders; and OR 1.102 95\% 1.0774-1.1272 for all-cause cancer). Again, the estimates for mortality were found higher than for incidence in all three comorbidity variables.

Finally, sex (comparing females to males) showed a positive significant effect on the incidence of COVID-19 (OR 1.772 95\% 1.7577-1.7870) and a non-significant effect on the mortality (OR $1.03495 \%$ 0.9974-1.0724). It also showed a non-significant effect on COVID-19 mortality when tested unadjusted.

We found a positive association between COVID-19 mortality and the annual average of both pollutants $\left(\mathrm{NO}_{2}\right.$ and $\left.\mathrm{PM}_{10}\right)$. Our model showed that, when the rest of covariates held constant, an increase of $10 \mu \mathrm{g} / \mathrm{m}^{3}$ in $\mathrm{NO}_{2}$ and $\mathrm{PM}_{10}$ annual average multiplied the odds of COVID-19 mortality by 1.138 (95\% 1.1245-1.162) and by 1.598 (95\% 1.5104-1.6936), respectively. Regarding COVID-19 incidence, $\mathrm{PM}_{10}$ also showed a positive association with COVID-19 incidence (OR 1.003 95\% 1.0015-1.0038), while $\mathrm{NO}_{2}$ showed a negative association when tested adjusted for the rest of covariates (OR 0.999 95\% 0.9989-0.9996).

As to the type of agri-food industries, we found several types that showed a reduced risk of both COVID-19 incidence and mortality (fish industry, vegetable, animal oils and fats, grain mill, bakery, other food products, animal feeding, beverage industry and garden industry). Milk products showed a non-significant effect on COVID-19 incidence and a negative effect on COVID-19 mortality. In addition, meat and forest industry showed a positive effect on the incidence of COVID-19 (OR 1.002 95\% 1.0012-1.0019 for meat industry and OR 1.004 95\% 1.0011-1.0077 for forest industry) but a negative effect on the mortality (OR 0.995 95\% 0.9926-0.9965 for meat industry and OR 0.945 95\% 0.9278-0.9632 for forest industry. However, unlike forest industry, meat industry showed a positive significant effect when tested unadjusted, as well. Finally, leather and fur industry were the only type of agri-food industry that were associated with increased levels of both COVID-19 incidence (OR 1.070 95\% 1.0624-1.0779) and of COVID-19 mortality (OR 1.110 95\% 1.0776-1.1441).

Regarding LULC data, we found a decreased risk of COVID-19 incidence for ilrIndustrial areas and ilr-Agricultural areas. In other words, when the relative dominance of industrial areas and agricultural areas were doubled in a given BHA with respect to the rest of LULC categories, the odds for COVID-19 incidence was expected to be reduced by a $0.010 \%(95 \% 0.0079-0.0116)$ and $0.018 \%(95 \% 0.0165-0.0194)$, respectively. On the other hand, for ilr-Urban areas and ilr-Forested areas the odds for COVID-19 incidence was expected to be increased by $0.006 \%$ (95\% $0.0048-0.0076)$ and $0.014 \%(95 \% 0.0131-0.0158)$, respectively. As for the COVID-19 mortality, ilr-Urban and ilr-Industrial areas showed positive significant effects (OR 1.050 95\% 1.0440-1.0569, and OR 1.039 95\% 1.0304-1.0477, respectively), while ilr-Agricultural and ilr-Forested areas showed negative significant effects (OR 0.936 95\% 0.9303-0.9422 and OR 0.991 95\% 0.9856-0.9971, respectively)

\section{Main Model Adjustment}

For illustrative purposes, the main model adjustment is shown for COVID-19 cases and deaths instead of the incidence and mortality rate. We noted no important differences 
between the expected values for males and for females for the main model. Thus, we assessed the model with the total number of cases and deaths (females + males).

Figure 1 shows a scatter plot were the observed number of COVID-19 cases (on the left) and deaths (on the right) are plotted against the expected number of COVID-19 cases and deaths predicted by the model. Those BHA which fulfilled the criterion that the difference between the observed rate and the fitted rate was either $>0.03$ or $<0.03$ (for COVID-19 cases), and $>0.004$ or $<0.004$ (for COVID-19 deaths) were identified as outliers.
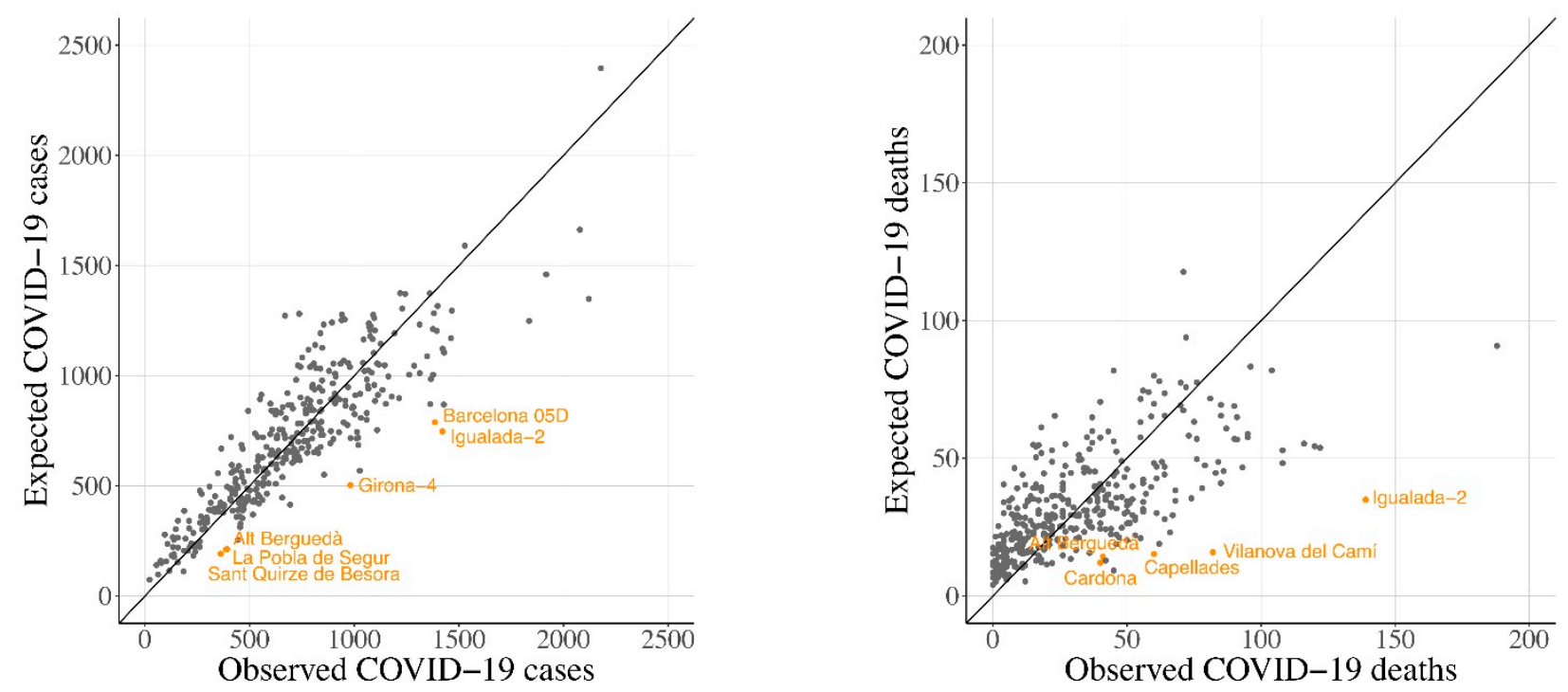

Figure 1. Scatter plot of the observed number of COVID-19 cases (left) and deaths (right), and the expected value predicted by the main model, logarithmic transformation has been performed.

The outliers coincide with either northern BHAs with high amounts of forest and semi-natural areas, low population and high incidence and mortality cases, or with regions from Central Catalonia where incidence and mortality were also high ("Barcelona 05D", "Girona-4", "Alt Berguedà", "la Pobla de Segur", "Sant Quirze de Besora" and "Igualada-2" for COVID-19 cases, Figure 1 left; and "Cardona", "Alt Berguedà", "Capellades", "Vilanova del Camí" and "Igualada-2" for COVID-19 deaths, Figure 1 right). As a matter of fact, two of the observed outliers ("Vilanova del Camí" and "Igualada-2") were BHAs in which the early outbreaks of the pandemic occurred.

Additionally, Figures 2 and 3 show the observed number of COVID-19 cases and deaths (on the left) and the expected number of cases and deaths (on the right) for each BHA predicted by the main model. In purple, there are represented those BHAs where the expected value was overestimated (difference between observed cases or deaths and expected cases or deaths $<$ Q1) by the main model. On the other hand, in orange there are represented those BHAs where the expected value was underestimated (difference $>$ Q3) by the main model. In green, those BHAs where the difference between the observed value and the expected fell within the Q1 and the Q3 are plotted. 

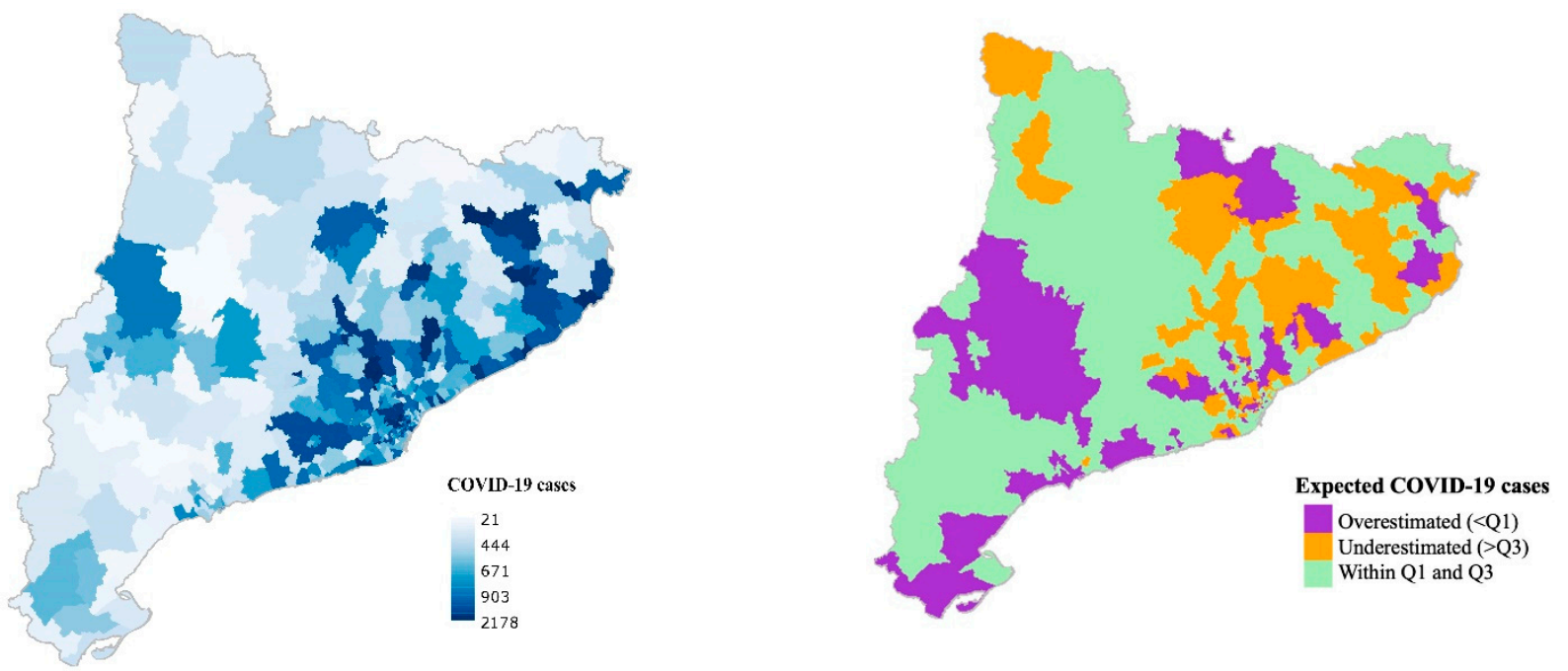

Figure 2. Number of observed COVID-19 cases (left) and the quartile distribution of the number of expected COVID-19 cases predicted by the main model (right).
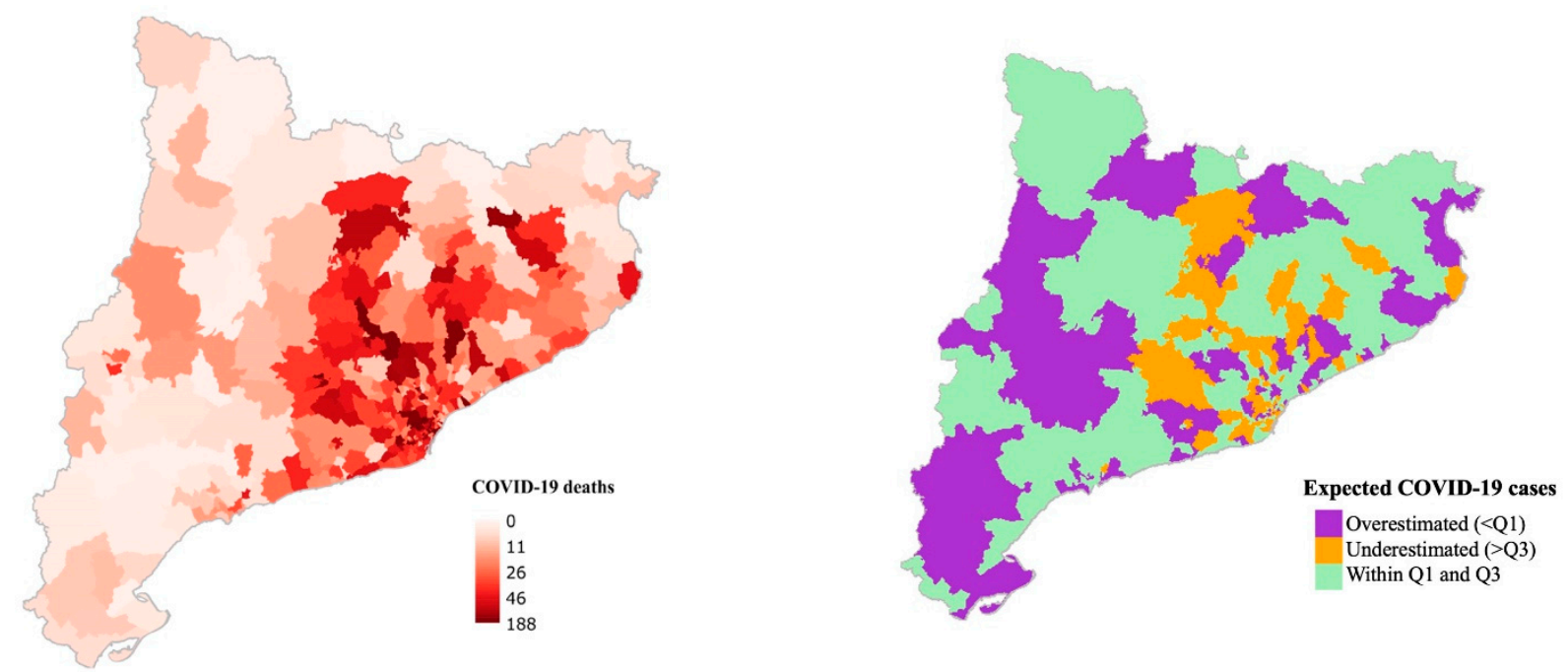

Figure 3. Number of observed COVID-19 deaths (left) and the quartile distribution of the number of expected COVID-19 deaths predicted by the main model (right).

\section{Discussion}

This cross-sectional study aimed to evaluate the associations between COVID-19 incidence and mortality and long-term exposition to air pollution $\left(\mathrm{NO}_{2}\right.$ and $\left.\mathrm{PM}_{10}\right)$ while adjusting for demographic (sex, percentage of people aged above 65 years), socioeconomic (quintile division of the Composed Socioeconomic Index) and comorbidity data (percentage of people presenting cardiovascular disease, psychological disorders and all-cause cancer). Additionally, for the first time, the contribution of agri-food industry type and the overall Land Use and Land Cover data was also explored to explain the geographical distribution of COVID-19 incidence and mortality, leading to novel results.

\subsection{Demographics}

Registered cases of COVID-19 in Catalonia have a clear female predominance $(165,597$ cases in females compared to 95,317 cases in males). Compared to other nations, the proportion of women in the incidence rate is only surpassed by Wales $(63.46 \%$ vs. $64.18 \%)$, while being still slightly higher than the Netherlands (62.45\%), Scotland (62.01\%), Northern Ireland (61.94\%), or Sweden (59.37\%) [56]. Mortality was also higher among females 
(50.41\%), but below what has occurred in Finland (52.00\%) and the Republic of Ireland $(50.50 \%)$ [56]. Catalonia has a positive small prevalence of female population (50.9\%). In addition, this predominance positively increases for people older than 65 years $(57.0 \%)$, while being reversed in 0-24-year-old children (around 48.6\%) [57]. With older people being the most affected by COVID-19 and the younger the least (in the early stages of the pandemic), women might be expected to carry most of the burden. In addition, research has highlighted women as composing the majority of the healthcare workforce in the US, and also with roles requiring more close and prolonged contact with patients [58]. Furthermore, for employed women or single parents, gender disparities may even be accentuated, as women are disproportionally responsible for the bulk of domestic tasks, including not only childcare but also eldercare [59]. These factors might explain our results showing women having $77.2 \%$ more risk of COVID-19 infection than males.

However, other countries with comparable age-gender pyramids (younger male population and older female population), such as Italy or the United States [60], have not experienced this phenomenon, following the global trend of male predominance [61,62].

However, we did not find greater risk of COVID-19 mortality for females, as the number of deaths for females and males was not significantly different (6098 and 5998, respectively).

Recent studies have pointed out that older age is as a major individual risk factor for severity of the COVID-19 infection and mortality [58,63]. We detected this effect in the adjusted and non-adjusted models for both COVID-19 infection and mortality. Nevertheless, the effect of age was reduced when adjusted for the rest of covariates.

\subsection{Socioeconomics}

Previous studies have suggested that socioeconomically deprived groups were associated with a higher risk of confirmed COVID-19 infection [64]. At the beginning of the outbreak, some authors suggested that working class people might be more exposed to the virus, as they were associated with the use of public transport [65]. However, other reports encouraged its use as the incidence of COVID-19 attributed to public appeared to be very low [66], even though safety countermeasures should be taken into account [67]. Regarding deprived people, some authors suggest that this group might face several disadvantages which make physical distancing a difficult issue [68]. That is, besides showing greater mobility due to the impossibility of working from home, lower-income population might tend to visit denser places (grocery stores, religious establishments, etc.), and spend longer times than upper class populations [69]. In Catalonia, some studies observed higher incidence of COVID-19 in poorer areas of Barcelona city [70].

Despite all the research showing a greater impact of COVID-19 on lower SES classes, our results seem to point to the other way around. We found higher incidence and mortality ratios for higher SES BHAs compared to medium SES. This effect was significant before and after adjusting for the rest of the covariates. In addition, although a non-significant effect was found for low (D) and very low (E) SES BHAs when tested unadjusted, when adjusting them into the model, they showed a significant negative association with both COVID-19 incidence and mortality. It is possible that differences between SES classes in Catalonia were not as noticeable as they were in other regions (in the UK, for example [64]). However, it is also possible that the Composed Socioeconomic Index used to measure the SES at area level might be weak measurement to detect individual-based characteristics. Nevertheless, as shown elsewhere [69], using a more detailed unit of analysis (e.g., census area) or completing SES information with individual-based information [64] might result in better estimations as to the impact of SES on COVID-19 incidence and mortality.

\subsection{Comorbidities}

Chronic medical conditions have been linked to disproportionate morbidity due to SARS-CoV-2 virus [58]. Regarding previous literature on SARS-CoV, some authors have reported that cardiovascular comorbidities might be the most important components for 
predicting adverse outcome, increasing the risk of death by twice as much as other risk factors [71]. In a recent meta-analysis [72], the proportion of cardia-cerebrovascular disease in patients with COVID-19 was found to be $16.4 \%$. A proportion much higher than what is found in the general population [72]. In this sense, many researchers acknowledge the consistent association between cardiovascular disease and SARS-CoV-2 [2,73-75].

In another sense, some researchers have reported that people diagnosed with psychological disorders had significantly higher odds of COVID-19 infection than people without a psychological disorder, with the strongest effect for depression and schizophrenia [76]. In the same way, these authors reported that the death rate for patients with both a recent diagnosis of psychological disorder and COVID-19 infection was higher than patients with COVID-19 infection but with no psychological disorder [76].

Other research also states the role of cancer in aggravating the prognostics of COVID19 [73]. In this regard, people with ongoing cancer treatments have shown higher risk because their immune system is compromised [77].

Our results are aligned with previous literature showing increased risk for both COVID-19 infection and mortality for those areas with more percent of people suffering from cardiovascular disease, psychological disorders and all-cause cancer. Similar to previous literature, we used these variables to control for the general health status of the BHAs, building our main model. They all showed a positive significant association with both COVID-19 infection and mortality before and after adjustment. This research adds evidence that these comorbidity variables are significant predictors.

Additionally, other relevant comorbidities such as obesity [78] or respiratory illnesses (e.g., COPD [79] and asthma [2]) have also been found to be positively associated with both infection and mortality for COVID-19. Our study was not able to control for these variables as we lacked the information. However, future studies might also use respiratory illnesses to describe the general health statutes of the unit of analysis.

\subsection{Air Pollution}

The major route of transmission for COVID-19 is through small droplets and aerosols of different sizes exhaled by an infected person when breathing, talking, coughing or sneezing [29,80,81]. Additionally, some research suggests the rapid spread of the SARS-CoV-2 could be explained by air pollution-to-human transmission (e.g., airborne transmission) [17-19]. Considering that the data used in this paper was historical (2016), we could not assess the relationship between short-term exposition to high levels of air pollutants (e.g., $\mathrm{PM}_{10}$ ) and the COVID-19 incidence or mortality and hence, provide evidence neither supporting these hypotheses nor against them.

In our opinion, the principal pathway linking air pollution to increased levels of COVID-19 incidence and mortality is the worse health status of more exposed populations $[29,82,83]$.

Long-term exposure to air pollution has been widely linked to cardiovascular diseases, respiratory illnesses, psychological disorders and cancer [84-86]. We believe that this might explain the association between more polluted areas and more severe and lethal forms of COVID-19 [26,80]. In this sense, areas more chronically exposed to higher air pollution levels would presumably be in worse health status and thus, showing increasing levels of COVID-19 mortality. Regarding the incidence of the virus, the positive association between increased pollutant levels and increased incidence levels of COVID-19 (at least for PM PM) $_{10}$ would be explained as during the early stages of the pandemic, people with pre-existent health conditions, or with more severe symptoms, were more likely to be tested, and thus, to finally be diagnosed as a new case.

As shown elsewhere [87], $\mathrm{NO}_{2}$ and $\mathrm{PM}_{10}$ effects on COVID-19 mortality remained significant after adjusting for socioeconomic, demographic and health-related variables. When adjusted in the model, $\mathrm{NO}_{2}$ showed a negative association with COVID-19 infection levels. In this sense, other relevant research conducted in Catalonia [88] highlights an association between $\mathrm{NO}_{2}$ and COVID-19 incidence, but the association was only found in 
more polluted BHAs. Our approach of using this data for all Catalonia without stratifying for more polluted areas might prevent us from detecting the aforementioned effect.

\subsection{Forest, Meat, and Leather and Fur Industry}

Our results show a significant positive effect of forested areas on COVID-19 incidence. Although forest industries might apparently be more abundant in BHAs with more forested areas, its positive effect was only found when it was adjusted, showing a significant negative effect when tested alone. We hypothesise that, rather than a positive independent effect for forest industry on COVID-19 incidence, possible associations with some main model covariates might have contributed to changing the direction of the effect.

In Catalonia, there is a huge production of pork meat, with a degree of self-sufficiency of $228.73 \%$, that has been constantly growing in recent decades [89]. While swine breeding is concentrated in Lleida region and Central Catalonia, most slaughterhouses and pork meat industries are located in Central Catalonia and Girona region [89]. Working conditions in slaughterhouses and meat industries such as low temperatures, high humidity, overcrowding, physical effort and other things may contribute to amplifying virus viability and transmission [90]. These conditions might also be found in other types of industries with high working density, making them prone-to-infection industries. However, apart from forest industries, we only found animal-related industries, namely the meat industry and the leather and fur industry, to be related with COVID-19 incidence and mortality (only the leather and fur industry).

In other coronavirus infections such as MERS, there was a high prevalence of infection in slaughterhouse workers compared to the general population [91]. COVID-19 transmission has been reported in the meat and poultry industry [13] and slaughterhouses are now considered a new front line in the COVID-19 pandemic [92]. In the same direction, local outbreaks in the fur industry have also been reported, particularly in the mink furriery $[93,94]$. The fact that this particular economic activity is significantly increasing both the incidence and the mortality rate in our model makes it plausible that this kind of industry poses a unique and independent risk for COVID-19 transmission.

In a recent study from the Netherlands [94], the authors reported that minks are susceptible for SARS-CoV-2. In addition, that infected animals are able to transmit the virus among each other. The authors also claim that although mink farms are present in other countries in Europe, China and the US, only the Netherlands has reported SARS-CoV-2 infections in these animals. In our study, we did not identify the animal species of the leather and fur industries we assessed. However, and given the results shown, more attention and research should be placed upon this specific industry.

In this sense, it is advised that COVID-19 pandemic should trigger a profound transformation of industrial animal agriculture by improving living conditions and increasing their space through extensive farming, diversify the protein source industry to increase far more sustainable plant-based market shares, and empowering the ecological transition of animal farmers [95].

\subsection{Land Use and Cover}

LULC data has been shown to be a suitable describer for the environment surrounding individuals in studies linking the environment to human health [41]. Unlike other environmental data sets, they combine both the biophysical (e.g., temperature, humidity, soil features) and socioeconomic (e.g., political, economic, cultural) drivers of a territory $[40,96]$. Given the uneven geographical distribution of the virus in Catalonia, we wanted to screen whether environmental composition of the BHAs (seen as urban, industrial, agricultural and forested areas) might be related with the impact of COVID-19.

Urban areas and industrial, commercial and transport units are known to be more associated with air pollution, aerosol emission, human mobility and higher population density [97]. These factors might be the reasons behind the increased risk of COVID19 mortality shown by the two ilr-transformed LUC categories, and an increased risk of 
COVID-19 infection for urban areas. Industrial areas showed a negative association with the incidence of COVID-19. This suggests that rather than the extension of the LULC category, the type of industry might be more relevant (as appreciated for agri-food industries).

On the other hand, agricultural areas and forested areas are more related to better air quality $[34,38,98,99]$, which might lead to higher general health status. That, in turn, might explain the negative association for both categories with COVID-19 mortality. However, despite people remaining under lockdown during most of the period analysed in this paper, agricultural tasks were considered essential services. These tasks mainly include individual work and are frequently done outdoors. Additionally, agricultural areas tend to be less populated which increases social distancing. We hypothesise that these aspects might have prevented regions with higher agricultural areas to easily register COVID-19 cases.

Although forest and semi-natural areas showed a decreased risk of COVID-19 mortality, the increased risk for COVID-19 incidence was somewhat a surprising result. Forested areas are widely known for their air purification role [38]. Furthermore, vegetation can also lessen other determinant variables for aerosol dispersion such as wind speed. In the same direction, areas with an increased amount of forest are associated with less population density and hence, more physical distancing. In Catalonia, the BAHs with the highest amount of forest and semi-natural areas tend to be sparsely populated. Moreover, many of these BAHs held second residences, mainly belonging to people living in the Metropolitan Area of Barcelona, who may have commuted to the countryside as soon as the emergency state was declared [100]. In these regions, few cases can be translated into high incidence rates, which might explain the increased risk of COVID-19 infection for higher levels of forested areas.

During the first wave of the pandemic, people remained at home, decreasing human interactions. In future studies, LULC data might be leveraged encompassing variables such as population density, air quality, biodiversity and economic activities to further validate LULC data in scenarios with mobile people.

\subsection{Limitations}

We implemented a cross-sectional design, so we could not escape from many of the limitations of ecological regression analysis highlighted elsewhere [46]. One of the major constraints is that, when using these designs, causal inference cannot be spotted. Nevertheless, these studies do leverage data for an entire population (Catalonia in our case) and are able to make conclusions at the area level (e.g., BHAs), which might be useful for policy-making [46]. Furthermore, the associations detected in this paper can provide justification for ongoing or future research.

We did not study the evolution of the epidemic taking place later than the 18 May 2020. As for age groups, we only controlled for the percentage of elder people ( $>65$ years). However, the advance of the epidemic has shown that many other age groups are vulnerable and should be considered in further analyses.

Controlling for other pre-existent health conditions such as obesity or respiratory illnesses and incorporating a greater variety of human mobility data (in scenarios with mobile people) such as the public transport network may enhance future research.

Although we controlled for significant differences for the pollutant concentration levels between 2016 and 2018/2019, accounting for the most recent modelling of the $\mathrm{NO}_{2}$ and $\mathrm{PM}_{10}$ annual average $\left(\mu \mathrm{g} / \mathrm{m}^{3}\right)$ in Catalonia may have improved the analysis as well. Furthermore, controlling for other air pollutants such as $\mathrm{O}_{3}$ or $\mathrm{PM}_{2.5}$, which have been described as relevant in previous research, might enhance future research.

In the same direction, the incapability for acquiring more updated data led us to use different datasets from different years for all the assessed covariates. However, the estimations found are consistent with previous research, which adds evidence as to the independent effect of the covariates assessed. 


\section{Conclusions}

Recent literature has highlighted the importance of controlling for covariates in studies linking air pollution to COVID-19. We used a main model with demographic, socioeconomic and comorbidity covariates highlighted from previous research as important predictors. This allowed us to take a glimpse of the independent effect of each explanatory variable when controlled for the main model covariates. Our findings are aligned with previous research showing that the baseline features of the regions in terms of health status, pollutant concentration levels $\left(\mathrm{NO}_{2}\right.$ and $\left.\mathrm{PM}_{10}\right)$, type of agri-food industry and type of land use and land cover have modulated the impact of the COVID-19 at a regional scale. A warning is made regarding future pandemics caused by respiratory infectious diseases. Thus, actions that improve air quality, diversify economic activities and enhance overall public health should be considered, not only to weaken the intensity of the current coronavirus, but for other virus-related problems expected to come.

Supplementary Materials: The following are available online at https:/ / www.mdpi.com/article /10.3390/ijerph18073768/s1, Figure S1: COVID-19 incidence rate, data from the beginning of the epidemic to the 18th of May 2020, Figure S2: COVID-19 mortality rate, data from the beginning of the epidemic to the 18th of May 2020, Figure S3: $\mathrm{NO}_{2}$ annual weighed average in $\mu \mathrm{g} / \mathrm{m}^{3}$ at BHA level (2016), Figure S4: $\mathrm{PM}_{10}$ annual weighed average in $\mu \mathrm{g} / \mathrm{m}^{3}$ at BHA level (2016), Figure S5: Reclassification of the 25 categories of the Land Use and Land Cover map of Catalonia (2017) into the 4 broader categories, Figure S6: Odds ratios and 95\% CI. Associations between COVID-19 incidence (in blue) and mortality (in red) and the rest of covariates. The main model controlled for demographics, socioeconomics, and comorbidity covariables. Human activity covariates as well as land use and cover covariates were included in the model separately.

Author Contributions: Conceptualization, Q.Z.-A. and F.C.iL.; methodology, M.S. and I.S.; validation, D.P. and M.S.; formal analysis, Q.Z.-A. and I.S.; investigation, Q.Z.-A. and F.C.iL.; resources, R.M. and J.O.-V.; data curation, Q.Z.-A.; writing—original draft preparation, Q.Z.-A.; writing-review and editing, A.B.; visualization, A.B.; supervision, R.M., I.S. and M.S.; project administration, R.M.; funding acquisition, R.M. All authors have read and agreed to the published version of the manuscript.

Funding: Quim Zaldo-Aubanell was supported by AGAUR FI fellowship (DOGC num. 7720, of 5.10.2018). Marc Saez was partially financed by the SUPERA COVID19 Fund, from SAUN: Santander Universidades, CRUE and CSIC, and by the COVID-19 Competitive Grant Program from Pfizer Global Medical Grants. E. David Pino acknowledge the support of the Spanish government project CGL2016-75996-R (MICINN) The funding sources did not participate in the design or conduct of the study, the collection, management, analysis, or interpretation of the data, or the preparation, review, or approval of the manuscript.

Institutional Review Board Statement: Not applicable.

Informed Consent Statement: Not applicable.

Data Availability Statement: 3rd Party Data. Restrictions apply to the availability of these data. Data was obtained from the RSAcovid19 records and are available with the permission of the Catalan Health Department.

Conflicts of Interest: We have no conflict of interests for the paper titled: "Community risk factors in the COVID-19 incidence and mortality in Catalonia. A population-based study".

\section{References}

1. WHO Coronavirus Disease (COVID-19) Situation Report-131. Available online: https://www.who.int/emergencies/diseases/n ovel-coronavirus-2019/situation-reports (accessed on 31 May 2020).

2. Yang, J.; Zheng, Y.; Gou, X.; Pu, K.; Chen, Z.; Guo, Q.; Ji, R.; Wang, H.; Wang, Y.; Zhou, Y. Prevalence of comorbidities and its effects in patients infected with SARS-CoV-2: A systematic review and meta-analysis. Int. J. Infect. Dis. 2020, 94, 91-95. [CrossRef] [PubMed]

3. Vivanco-Hidalgo, R.M.; Vela, E.; Clèries, M.; Monterde, D. Informe Sobre les Característiques Sociodemogràfiques, Clíniques i els Factors Pronòstics dels Pacients amb el Diagnòstic de COVID-19 a Catalunya; Generalitat de Catallunya. Agència de Qualitat i Avaluació Sanitàries de Catalunya: Barcelona, Spain, 2020. (In Catalan) 
4. Bialek, S.; Bowen, V.; Chow, N.; Curns, A.; Gierke, R.; Hall, A.; Hughes, M.; Pilishvili, T.; Ritchey, M.; Roguski, K.; et al. Geographic Differences in COVID-19 Cases, Deaths, and Incidence-United States, February 12-April 7, 2020. MMWR Morb. Mortal. Wkly. Rep. 2020, 69, 465-471. [CrossRef]

5. Brandt, E.B.; Beck, A.F.; Mersha, T.B. Air pollution, racial disparities and COVID-19 mortality. J. Allergy Clin. Immunol. 2020. [CrossRef] [PubMed]

6. Paez, A.; Lopez, F.A.; Menezes, T.; Cavalcanti, R.; da Rocha Pitta, M.G. A Spatio-Temporal Analysis of the Environmental Correlates of COVID-19 Incidence in Spain. Geogr. Anal. 2020, gean.12241. [CrossRef]

7. Pequeno, P.; Mendel, B.; Rosa, C.; Bosholn, M.; Souza, J.L.; Baccaro, F.; Barbosa, R.; Magnusson, W. Air transportation, population density and temperature predict the spread of COVID-19 in Brazil. PeerJ 2020, 8, e9322. [CrossRef]

8. Gerli, A.G.; Centanni, S.; Miozzo, M.R.; Virchow, J.C.; Sotgiu, G.; Canonica, G.W.; Soriano, J.B. COVID-19 mortality rates in the European Union, Switzerland, and the UK: Effect of timeliness, lockdown rigidity, and population density. Minerva Med. 2020. [CrossRef]

9. Adiga, A.; Wang, L.; Sadilek, A.; Tendulkar, A.; Venkatramanan, S.; Vullikanti, A.; Aggarwal, G.; Talekar, A.; Ben, X.; Chen, J.; et al. Interplay of global multi-scale human mobility, social distancing, government interventions, and COVID-19 dynamics. medRxiv 2020. [CrossRef]

10. Badr, H.S.; Du, H.; Marshall, M.; Dong, E.; Squire, M.M.; Gardner, L.M. Association between mobility patterns and COVID-19 transmission in the USA: A mathematical modelling study. Lancet Infect. Dis. 2020, 19-21. [CrossRef]

11. da Camara Ribeiro-Dantas, M.; Alves, G.; Gomes, R.B.; Bezerra, L.C.T.; Lima, L.; Silva, I. Dataset for country profile and mobility analysis in the assessment of COVID-19 pandemic. Data Br. 2020, 31. [CrossRef]

12. Jiang, Y.; Wu, X.J.; Guan, Y.J. Effect of ambient air pollutants and meteorological variables on COVID-19 incidence. Infect. Control Hosp. Epidemiol. 2020, 41, 1011-1015. [CrossRef]

13. Waltenburg, M.A.; Victoroff, T.; Rose, C.E.; Butterfield, M.; Jervis, R.H.; Fedak, K.M.; Gabel, J.A.; Feldpausch, A.; Dunne, E.M.; Austin, C.; et al. Update: COVID-19 Among Workers in Meat and Poultry Processing Facilities-United States, April-May 2020. MMWR. Morb. Mortal. Wkly. Rep. 2020, 69, 887-892. [CrossRef]

14. European Federation of Food Agriculture and Tourism Trade Unions. EFFAT Report. Covid-19 Outbreaks in Slaughterhouses and Meat Processing Plants. State of Affairs and Proposals for Policy Action at EU Level; European Federation of Food Agriculture and Tourism Trade Unions: Brussels, Belgium, 2020.

15. Walrand, S. Autumn COVID-19 surge dates in Europe correlated to latitudes, not to temperature-humidity, pointing to vitamin D as contributing factor. Sci. Rep. 2021, 11, 1-9. [CrossRef]

16. Carleton, T.; Cornetet, J.; Huybers, P.; Meng, K.C.; Proctor, J. Global evidence for ultraviolet radiation decreasing COVID-19 growth rates. Proc. Natl. Acad. Sci. USA 2020, 118, 1-9. [CrossRef]

17. Morawska, L.; Cao, J. Airborne transmission of SARS-CoV-2: The world should face the reality. Environ. Int. 2020, 139, 105730. [CrossRef] [PubMed]

18. Hadei, M.; Hopke, P.K.; Jonidi, A.; Shahsavani, A. A letter about the airborne transmission of sars-cov-2 based on the current evidence. Aerosol Air Qual. Res. 2020, 20, 911-914. [CrossRef]

19. Frontera, A.; Martin, C.; Vlachos, K.; Sgubin, G. Regional air pollution persistence links to COVID-19 infection zoning. J. Infect. 2020, 81, 318-356. [CrossRef] [PubMed]

20. WHO Mortality and Burden of Disease from Ambient Air Pollution. Available online: https://www.who.int/gho/phe/outdoor_ air_pollution/burden/en/ (accessed on 31 May 2020).

21. Sciomer, S.; Moscucci, F.; Magrì, D.; Badagliacca, R.; Piccirillo, G.; Agostoni, P. SARS-CoV-2 spread in Northern Italy: What about the pollution role? Environ. Monit. Assess. 2020, 192. [CrossRef] [PubMed]

22. Frontera, A.; Cianfanelli, L.; Vlachos, K.; Landoni, G.; Cremona, G. Severe air pollution links to higher mortality in COVID-19 patients: The "double-hit" hypothesis. J. Infect. 2020. [CrossRef] [PubMed]

23. Wu, X.; Nethery, R.C.; Sabath, B.M.; Braun, D.; Dominici, F. Exposure to air pollution and COVID-19 mortality in the United States: A nationwide cross-sectional study. medRxiv 2020. [CrossRef]

24. Travaglio, M.; Popovic, R.; Yu, Y.; Leal, N.; Martins, L.M. Links between air pollution and COVID-19 in England. medRxiv 2020. [CrossRef]

25. Ogen, Y. Assessing nitrogen dioxide (NO2) levels as a contributing factor to coronavirus (COVID-19) fatality. Sci. Total Environ. 2020, 726, 138605. [CrossRef] [PubMed]

26. Tian, H.; Liu, Y.; Song, H.; Wu, C.-H.; Li, B.; Kraemer, M.U.G.; Zheng, P.; Yan, X.; Jia, G.; Zheng, Y.; et al. Risk of COVID-19 is associated with long-term exposure to air pollution. medRxiv 2020. [CrossRef]

27. Heederik, D.J.J.; Smit, L.A.M.; Vermeulen, R.C.H. Go slow to go fast: A plea for sustained scientific rigor in air pollution research during the COVID-19 pandemic. Eur. Respir. J. 2020, 2001361. [CrossRef] [PubMed]

28. Félix-Arellano, E.E.; Schilmann, A.; Hurtado-Díaz, M.; Texcalac-Sangrador, J.L.; Riojas-Rodríguez, H. Revisión rápida: Contaminación del aire y morbimortalidad por Covid-19. Salud Publica Mex. 2020, 62, 1-8. [CrossRef] [PubMed]

29. Saez, M.; Tobias, A.; Barceló, M.A. Effects of long-term exposure to air pollutants on the spatial spread of COVID-19 in Catalonia, Spain. Environ. Res. 2020, 191. [CrossRef] 
30. Setti, L.; Passarini, F.; De Gennaro, G.; Barbieri, P.; Grazia Perrone, M.; Borelli, M.; Palmisani, J.; Di Gilio, A.; Torboli, V.; Pallavicini, A.; et al. SARS-Cov-2 RNA Found on Particulate Matter of Bergamo in Northern Italy: First Preliminary Evidence. medRxiv 2020. [CrossRef]

31. Comunian, S.; Dongo, D.; Milani, C.; Palestini, P. Air Pollution and Covid-19: The Role of Particulate Matter in the Spread and Increase of Covid-19's Morbidity and Mortality. Int. J. Environ. Res. Public Health 2020, 17, 4487. [CrossRef]

32. Setti, L.; Passarini, F.; De Gennaro, G.; Barbieri, P.; Pallavicini, A.; Ruscio, M.; Piscitelli, P.; Colao, A.; Miani, A. Searching for SARS-COV-2 on Particulate Matter: A Possible Early Indicator of COVID-19 Epidemic Recurrence. Int. J. Environ. Res. Public Health 2020, 17, 2986. [CrossRef]

33. Coccia, M. Factors determining the diffusion of COVID-19 and suggested strategy to prevent future accelerated viral infectivity similar to COVID. Sci. Total Environ. 2020, 729, 138474. [CrossRef]

34. Liu, J.; Ding, J.; Li, L.; Li, X.; Zhang, Z.; Ran, S.; Ge, X.; Zhang, J.; Wang, J. Characteristics of aerosol optical depth over land types in central Asia. Sci. Total Environ. 2020, 727, 138676. [CrossRef]

35. Guo, Y.; Hong, S.; Feng, N.; Zhuang, Y.; Zhang, L. Spatial distributions and temporal variations of atmospheric aerosols and the affecting factors: A case study for a region in central China. Int. J. Remote Sens. 2012, 33, 3672-3692. [CrossRef]

36. Zhang, W.; He, Q.; Wang, H.; Cao, K.; He, S. Factor analysis for aerosol optical depth and its prediction from the perspective of land-use change. Ecol. Indic. 2018, 93, 458-469. [CrossRef]

37. Feng, H.; Zou, B.; Tang, Y. Scale- and region-dependence in landscape-PM2.5 correlation: Implications for urban planning. Remote Sens. 2017, 9, 918. [CrossRef]

38. Liu, X.; Yu, X.; Zhang, Z. PM2.5 Concentration Differences between Various Forest Types and Its Correlation with Forest Structure. Atmosphere 2015, 6, 1801-1815. [CrossRef]

39. Zou, B.; Xu, S.; Sternberg, T.; Fang, X. Effect of land use and cover change on air quality in urban sprawl. Sustain. 2016, 8, 677. [CrossRef]

40. Turner, B.L.; Meyer, W.B.; Skole, D.L. Global Land-Use/Land-Cover Change: Towards an Integrated Study. R. Swedish Acad. Sci. 1994, 23, 91-95.

41. Zaldo-Aubanell, Q.; Serra, I.; Sardanyés, J.; Alsedà, L.; Maneja, R. Reviewing the reliability of Land Use and Land Cover data in studies relating human health to the environment. Environ. Res. 2021, 194. [CrossRef]

42. Muñoz Ortiz, L.; Mompart Penina, A.; Mias, M. Anàlisi de les Defuncions Observades i Esperades Durant L'epidèmia de COVID-19 a Catalunya; Generalitat de Catallunya; Agència de Qualitat i Avaluació Sanitàries de Catalunya: Barcelona, Spain, 2020.

43. Suñer, C.; Ouchi, D.; Àngel Mas, M.; Alarcon, R.L.; Mesquida, M.M.; Negredo, E.; Prat, N.; Bonet-Simó, J.M.; Miralles, R.; Teixidó Colet, M.; et al. Risk factors for mortality of residents in nursing homes with Covid-19: A retrospective cohort study. medRxiv 2020. [CrossRef]

44. Peckham, H.; de Gruijter, N.M.; Raine, C.; Radziszewska, A.; Ciurtin, C.; Wedderburn, L.R.; Rosser, E.C.; Webb, K.; Deakin, C.T. Male sex identified by global COVID-19 meta-analysis as a risk factor for death and ITU admission. Nat. Commun. 2020, 11, 1-10. [CrossRef] [PubMed]

45. Colls, C.; Mias, M.; García-Altés, A. A deprivation index to reform the financing model of primary care in Catalonia (Spain). Gac. Sanit. 2020, 34, 44-50. [CrossRef]

46. Wu, X.; Nethery, R.C.; Sabath, M.B.; Braun, D.; Dominici, F. Air pollution and COVID-19 mortality in the United States: Strengths and limitations of an ecological regression analysis. Sci. Adv. 2020, 6, 1-7. [CrossRef] [PubMed]

47. Benmarhnia, T. Linkages between air pollution and the health burden from covid-19: Methodological challenges and opportunities. Am. J. Epidemiol. 2020, 189, 1238-1243. [CrossRef] [PubMed]

48. Zhu, Y.; Xie, J.; Huang, F.; Cao, L. Association between short-term exposure to air pollution and COVID-19 infection: Evidence from China. Sci. Total Environ. 2020, 727, 138704. [CrossRef] [PubMed]

49. Johannes Andrée, B.P. Incidence of COVID-19 and Connections with Air Pollution Exposure: Evidence from the Netherlands. medRxiv 2020. [CrossRef]

50. Leininger, T.J.; Gelfand, A.E.; Allen, J.M.; Silander, J.A. Spatial Regression Modeling for Compositional Data With Many Zeros. J. Agric. Biol. Environ. Stat. 2013, 18, 314-334. [CrossRef]

51. Pearson, K. Mathematical contributions to the theory of evolution. Proeedings R. Soc. 1896, 60, 489-498.

52. Aitchison, J.; Egozcue, J.J. Compositional data analysis: Where are we and where should we be heading? Math. Geol. 2005, 37, 829-850. [CrossRef]

53. Hron, K.; Filzmoser, P.; Thompson, K. Linear regression with compositional explanatory variables. J. Appl. Stat. 2012, 39, 1115-1128. [CrossRef]

54. Müller, I.; Hron, K.; Fišerová, E.; Šmahaj, J.; Cakirpaloglu, P.; Vančáková, J. Interpretation of compositional regression with application to time budget analysis. Austrian J. Stat. 2018, 47, 3-19. [CrossRef]

55. R Core Team. R: A Language and Environment for Statistical Computing; R Foundation for Statistical Computing: Vienna, Austria, 2019. Available online: https:/ / www.R-project.org/ (accessed on 5 July 2020).

56. Global Health 5050 COVID-19 Sex-Disaggregated Data Tracker. Available online: https://globalhealth5050.org/covid19/sex-dis aggregated-data-tracker/ (accessed on 7 July 2020).

57. Institut d'Estadística de Catalunya Anuari Estadístic de Catalunya. Població a 1 de Gener. Per Sexe i Grups d'edat. Available online: https: / / www.idescat.cat/pub/ ?id=aec\&n=253 (accessed on 5 July 2020). 
58. Connor, J.; Madhavan, S.; Mokashi, M.; Amanuel, H.; Johnson, N.R.; Pace, L.E.; Bartz, D. Health risks and outcomes that disproportionately affect women during the Covid-19 pandemic: A review. Soc. Sci. Med. 2020, 266, 113364. [CrossRef] [PubMed]

59. Almeida, M.; Shrestha, A.D.; Stojanac, D.; Miller, L.J. The impact of the COVID-19 pandemic on women's mental health. Arch. Womens Ment. Health 2020, 23, 741-748. [CrossRef] [PubMed]

60. PopulationPyramid.net Population of WORLD. 2019. Available online: https://www.populationpyramid.net/ (accessed on 5 July 2020).

61. Sharma, G.; Volgman, A.S.; Michos, E.D. Sex Differences in Mortality from COVID-19 Pandemic: Are Men Vulnerable and Women Protected? JACC Case Rep. 2020. [CrossRef]

62. Maleki Dana, P.; Sadoughi, F.; Hallajzadeh, J.; Asemi, Z.; Mansournia, M.A.; Yousefi, B.; Momen-Heravi, M. An Insight into the Sex Differences in COVID-19 Patients: What are the Possible Causes? Prehosp. Disaster Med. 2020, 1-15. [CrossRef] [PubMed]

63. You, H.; Wu, X.; Guo, X. Distribution of covid-19 morbidity rate in association with social and economic factors in wuhan, china: Implications for urban development. Int. J. Environ. Res. Public Health 2020, 17, 341. [CrossRef] [PubMed]

64. Niedzwiedz, C.L.; O’Donnell, C.A.; Jani, B.D.; Demou, E.; Ho, F.K.; Celis-Morales, C.; Nicholl, B.I.; Mair, F.S.; Welsh, P.; Sattar, N.; et al. Ethnic and socioeconomic differences in SARS-CoV-2 infection: Prospective cohort study using UK Biobank. BMC Med. 2020, 18, 1-14. [CrossRef] [PubMed]

65. Zhen, J.; Chan, C.; Schoonees, A.; Apatu, E.; Thabane, L.; Young, T. Transmission of respiratory viruses when using public ground transport: A rapid review to inform public health recommendations during the COVID-19 pandemic. S. Afr. Med. J. 2020, 110, 478-483.

66. Hunt, M. Covid-19 Transmission Rates on Rail; RSSB: London, UK, 2020.

67. Shen, J.; Duan, H.; Zhang, B.; Wang, J.; Ji, J.S.; Wang, J.; Pan, L.; Wang, X.; Zhao, K.; Ying, B.; et al. Prevention and control of COVID-19 in public transportation: Experience from China. Environ. Pollut. 2020, 266, 115291. [CrossRef] [PubMed]

68. Khunti, K.; Singh, A.K.; Pareek, M.; Hanif, W. Is ethnicity linked to incidence or outcomes of covid-19? BMJ 2020, 369, 14-15. [CrossRef]

69. Chang, S.; Pierson, E.; Koh, P.W.; Gerardin, J.; Redbird, B.; Grusky, D.; Leskovec, J. Mobility network models of COVID-19 explain inequities and inform reopening. Nature 2020. [CrossRef]

70. Baena-Díez, J.M.; Barroso, M.; Cordeiro-Coelho, S.I.; Díaz, J.L.; Grau, M. Impact of COVID-19 outbreak by income: Hitting hardest the most deprived. J. Public Health (Bangkok) 2020, 1-6. [CrossRef]

71. Hu, X.; Deng, Y.; Wang, J.; Li, H.; Li, M.; Lu, Z. Short term outcome and risk factors for mortality in adults with critical Severe Acute Respiratory Syndrome (SARS). J. Huazhong Univ. Sci. Technol. Med. Sci. 2004, 24, 514-517. [CrossRef]

72. Li, B.; Yang, J.; Zhao, F.; Zhi, L.; Wang, X.; Liu, L.; Bi, Z.; Zhao, Y. Prevalence and impact of cardiovascular metabolic diseases on COVID-19 in China. Clin. Res. Cardiol. 2020, 109, 531-538. [CrossRef] [PubMed]

73. Guan, W.J.; Liang, W.H.; Zhao, Y.; Liang, H.R.; Chen, Z.S.; Li, Y.M.; Liu, X.Q.; Chen, R.C.; Tang, C.L.; Wang, T.; et al. Comorbidity and its impact on 1590 patients with Covid-19 in China: A Nationwide Analysis. Eur. Respir. J. 2020, 55. [CrossRef] [PubMed]

74. Onder, G.; Rezza, G.; Brusaferro, S. Case-Fatality Rate and Characteristics of Patients Dying in Relation to COVID-19 in Italy. JAMA J. Am. Med. Assoc. 2020, 323, 1775-1776. [CrossRef] [PubMed]

75. Li, X.; Wang, L.; Yan, S.; Yang, F.; Xiang, L.; Zhu, J.; Shen, B.; Gong, Z. Clinical characteristics of 25 death cases with COVID-19: A retrospective review of medical records in a single medical center, Wuhan, China. Int. J. Infect. Dis. 2020, 94, 128-132. [CrossRef] [PubMed]

76. Wang, Q.Q.; Xu, R.; Volkow, N.D. Increased risk of COVID-19 infection and mortality in people with mental disorders: Analysis from electronic health records in the United States. World Psychiatry 2021, 20, 124-130. [CrossRef] [PubMed]

77. Jindal, V.; Sahu, K.K.; Gaikazian, S.; Siddiqui, A.D.; Jaiyesimi, I. Cancer treatment during COVID-19 pandemic. Med. Oncol. 2020, 37, 1-3. [CrossRef]

78. Finer, N.; Garnett, S.P.; Bruun, J.M. COVID-19 and obesity. Clin. Obes. 2020, 10. [CrossRef]

79. Lee, S.C.; Son, K.J.; Han, C.H.; Park, S.C.; Jung, J.Y. Impact of COPD on COVID-19 prognosis: A nationwide population-based study in South Korea. Sci. Rep. 2021, 11, 1-8. [CrossRef]

80. Domingo, J.L.; Marquès, M.; Rovira, J. Influence of airborne transmission of SARS-CoV-2 on COVID-19 pandemic. A review. Environ. Res. 2020, 188, 17-20. [CrossRef]

81. Milton, D.K. A Rosetta Stone for Understanding Infectious Drops and Aerosols. J. Pediatr. Infect. Dis. Soc. 2020, 9, 413-415. [CrossRef]

82. Setti, L.; Passarini, F.; De Gennaro, G.; Barbieri, P.; Licen, S.; Perrone, M.G.; Piazzalunga, A.; Borelli, M.; Palmisani, J.; DI Gilio, A.; et al. Potential role of particulate matter in the spreading of COVID-19 in Northern Italy: First observational study based on initial epidemic diffusion. BMJ Open 2020, 10, 1-9. [CrossRef] [PubMed]

83. Li, H.; Xu, X.L.; Dai, D.W.; Huang, Z.Y.; Ma, Z.; Guan, Y.J. Air pollution and temperature are associated with increased COVID-19 incidence: A time series study. Int. J. Infect. Dis. 2020, 97, 278-282. [CrossRef] [PubMed]

84. Pope, C.A., III. Lung Cancer, Cardiopulmonary Mortality, and Long-term Exposure to Fine Particulate Air Pollution. JAMA 2002, 287, 1132. [CrossRef] [PubMed]

85. Franklin, B.A.; Brook, R.; Arden Pope, C. Air pollution and cardiovascular disease. Curr. Probl. Cardiol. 2015, 40, 207-238. [CrossRef] 
86. Power, M.C.; Adar, S.D.; Yanosky, J.D.; Weuve, J. Exposure to air pollution as a potential contributor to cognitive function, cognitive decline, brain imaging, and dementia: A systematic review of epidemiologic research. Neurotoxicology 2016, 56, 235-253. [CrossRef]

87. Travaglio, M.; Yu, Y.; Popovic, R.; Selley, L.; Leal, N.S.; Martins, L.M. Links between air pollution and COVID-19 in England. Environ. Pollut. 2021, 268, 115859. [CrossRef]

88. Ribas, V.; Miralles, F.; Rey, O.; Rafael, X.; Subías, P.; Torrent, M.; Vicens, J.A.; Saez, M.; Barceló, M.A.; Ponce-de-León, M.; et al. Big Data i Intel-Ligència Artificial per a la Prevenció D'epidèmies. Monitoratge i Predicció per a la Detecció Primerenca de brots Epidèmics; Generalitat de Catalunya. Departament de Polítiques Digitals i Administració Pública i el Departament de Salut: Barcelona, Spain, 2021; in press. (In Catalan)

89. García Hernández, E.; Sancho Gracia, V.; Pascual Vilarroya, S.; Cartanyà Ferre, J.; Blanco Abillá, G.; Dolz Dolz, N.; Babot Gaspa, D. Informe Anual del Sector Porcí; Edicions de la Universitat de Lleida: Lleida, Spain, 2018.

90. Kamau, E.; Ongus, J.; Gitau, G.; Galgalo, T.; Lowther, S.A.; Bitek, A.; Munyua, P. Knowledge and practices regarding Middle East Respiratory Syndrome Coronavirus among camel handlers in a Slaughterhouse, Kenya, 2015. Zoonoses Public Health 2019, 66, 169-173. [CrossRef]

91. Omrani, A.S.; Al-Tawfiq, J.A.; Memish, Z.A. Middle east respiratory syndrome coronavirus (Mers-coV): Animal to human interaction. Pathog. Glob. Health 2015, 109, 354-362. [CrossRef]

92. Middleton, J.; Reintjes, R.; Lopes, H. Meat plants-a new front line in the covid-19 pandemic. BMJ 2020, 370, m2716. [CrossRef]

93. Enserink, M. Coronavirus rips through Dutch mink farms, triggering culls. Science 2020, 368, 1169. [CrossRef] [PubMed]

94. Oreshkova, N.; Molenaar, R.J.; Vreman, S.; Harders, F.; Oude Munnink, B.B.; Hakze-van der Honing, R.W.; Gerhards, N.; Tolsma, P.; Bouwstra, R.; Sikkema, R.S.; et al. SARS-CoV-2 infection in farmed minks, the Netherlands, April and May 2020. Euro Surveill. 2020, 25. [CrossRef] [PubMed]

95. Garcés, L. COVID-19 exposes animal agriculture's vulnerability. Agric. Hum. Values 2020, 1, 3. [CrossRef]

96. Boada, M.; Gomez, F.J. Boscos de Catalunya; Lunwerg: Barcelona, Spain, 2012; ISBN 9788497859318.

97. Hidalgo, J.; Masson, V.; Baklanov, A.; Pigeon, G.; Gimeno, L. Advances in urban climate modeling. Ann. N. Y. Acad. Sci. 2008, 1146, 354-374. [CrossRef]

98. Demir, M.; Dindaroğlu, T.; Yilmaz, S. Effects of forest areas on air quality; Aras Basin and its environment. J. Environ. Health Sci. Eng. 2014, 12, 1-11. [CrossRef]

99. Mcdonald, A.G.; Bealey, W.J.; Fowler, D.; Dragosits, U.; Skiba, U.; Smith, R.I.; Donovan, R.G.; Brett, H.E.; Hewitt, C.N.; Nemitz, E. Quantifying the effect of urban tree planting on concentrations and depositions of PM 10 in two UK conurbations. Atmos. Environ. 2007, 41. [CrossRef]

100. Codinas, M.; Sans, C. Alcaldes del Pirineu Denuncien L'arribada de Turistes de Segones Residències. Available online: https:/ / www.segre.com/noticies/comarques /2020/04/09/alcaldes_del_pirineu_denuncien_arribada_turistes_segones_resid encies_103590_1091.html (accessed on 3 July 2020). 